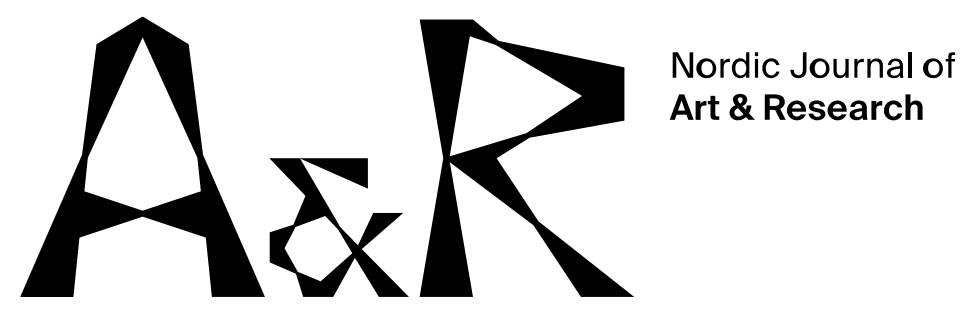

\title{
Foreword
}

\section{Reasons for Hope}

\author{
Tia DeNora ${ }^{1}$ \\ University of Exeter and University of Bergen
}

As I write this foreword, it has been a year since the Art in Education Conference at OsloMet. It feels, given what's happened since then, like a much longer time. Looking over my notes from the session presentations l'm struck, in retrospect, by the prescience of the conference's recurring themes and values. Those included play, preparation, resilience, sustainability, difference, openness, enablement, transcendence, hope for the future, social justice, accommodation, adaptation, tolerance.

The original Conference Call for Papers talked about a 'rapidly changing and increasingly pluralistic' world. I do not suppose that any of us had expected the momentous combination of events of 2020 (and the year is not yet over). And I do not suppose then that any of us, despite our already clear commitment to the importance of arts and artistic engagement in social life, had any inkling of what would so shortly develop, putting our daily lives as we knew them on hold, and placing the matter of global inequalities front and centre stage. I am writing this foreword on the anniversary of the 1963 March on Washington for Jobs and Freedom (the occasion of Martin Luther King Jr's 'I have a dream' speech). Five days ago, a fresh wave of violence and protest erupted in Wisconsin after police shot Jacob Blake in the back as he was entering his car where his children were seated. The Covid-19 virus shows signs of flaring up again. And I doubt that by the time this Special Issue is in print

\section{T.DeNora@exeter.ac.uk}


these troubles and challenges will have been resolved. The question thus arises - is there reason for hope? And, in the context of this special Issue, what, if anything, can be gained by thinking about - and with - the arts in our troubled times?

To different degrees, many of us have been isolated and there has been time - it may feel at times perhaps like too much time - for thinking. In fact, that has been no bad thing. For one, it has meant we've had time to become more aware of global problems and challenges, and, for those of us currently leading so-called comfortable lives, to at least try to consider how we might contribute to the wider circumstances of others in need. Discussions have been initiated from various quarters, and taken various shapes, about what kind of world we desire, post-Covid. There are similarities to previous post-apocalyptic visions of how to make things in the future - we hope better. Social media, news media, our daily conversations - all of these are scenes for these discussions which, for the most part, now take place online, on screen, and over the telephone. Food production and distribution, new economic structures, transport, housing, immigration and asylum, non-violence, the environment, social equality, education, employment, meaningful occupation, equitable healthcare, and much more - until the head swims. At times these visions, which of course are often contrary, are grand, maybe even too grand? And yet they are undoubtedly fuelled by imagination, by the desire to make things different, to show what things could be like and to represent and hold on to things that we love and think are good. All of them thus involve creativity. Indeed, insofar as our collective desires for improvement involve the impulse to make and to create, these utopian impulses involve artification; that is, they attempt to place things that we value within a frame to draw them to others' attention and concern.

The last half year has encouraged us to locate new kinds of resources for quality of life. Creativity has come to the fore as a way of maintaining social ties and as a way of simply continuing and responding to events. For relatively wealthy folk it has taken myriad minor, mundane forms - elbow tapping rather than handshakes, home-crafted face masks, rainbows painted all over the place, singing from balconies, staycations, tomatoes growing in a window, home-baked bread. I have lost count of how many families have acquired a kitten. But at a more serious level it has led to adaptations around work and, in the UK where the problem is huge, some rapid responses in the form of housing for homeless people (which may shortly come to an end, sparking discussions about affordability and space). At the same time, the traditional locus of what we normally speak of as 'creative industries' has been put on hold (web-gallery exhibitions, radio plays and live streamed concerts performed to empty halls notwithstanding). And of course, schools and universities, at least until recently have 
been closed, and are now restarting, in some countries amid growing concern. It is perhaps one of the ironies of Covid-19 that - just when they might be of help - we have been barred from the kinds of physical spaces capable of fostering imagination, motivating us (as a kind of life support) and helping to define us severally and together, our similarities and our differences. For surely, both the arts, and schools when they work properly - expose us to difference in and over time.

In our globally linked, multi-cultural worlds with their ebbs and flows of people across continents and the digitised connections between these people, the question of 'difference' has become urgent. Against a dominant backdrop of neo-liberalism, there is too often a kind of token nod to this matter, one that tends to reify difference into categories or identity 'types' with quick fix resolutions. And yet, the play of difference in real time and space looks, or can look, very - different. For one, it is not as simple as trying to 'teach the world to sing' and it cannot be accomplished from the top-down (Bergh 2007). For another, there are differences within categories as well as between them which, over the years, Black feminism and intersectionality have helped to clarify. And this has put the spotlight on difference, and sameness, as they are produced, in situ.

Which in turn puts the spotlight on the temporality of differences. Differences arise (or recede) every minute and every day for all of us, albeit not always in ways that we can consciously acknowledge. They underscore 'us' as characterised by different things at different times and multiply dimensioned. This multiplicity provokes, I think, an existential question, one that is answered in, and through, our capacity for participation in events over time and space. And it is here, at least in my experience (research and personal) that what happens to us and what we cause, or contribute to causing, split second by split second, day by day, takes shape within ecologies of action. It is within these ecologies that we can observe the arts, or rather aesthetic media, in terms of how they contribute to the production of realities in our daily lives, how they help to frame perception, how they offer exemplars and affordances for being, feeling, and acting.

For example, over the past 18 months I've been involved in a project called Care for Music (2019-22). In company with music therapists and community musicians (Gary Ansdell, Randi Rolvsjord, Wolfgang Schmid) I've been examining how and why people living in residential care homes and hospices in the UK and Norway 'care' for music, and what this means in terms of practicalities, logistics and aesthetics.

Needless to say, the conduct of this work has been profoundly affected by the Covid19 pandemic but we have found some ways around that, working in tandem with care 
Tia DeNora. Foreword: Reasons for Hope

staff, adapting to online formats. And we are starting to sense some very preliminary findings.

One of the first things we noticed was that 'difference' is enriching. Discovering the possibilities that 'de-formed' sound formats (and 'compromised' communication) offered for relating to each other was one 'finding'. (Question: does it 'matter' if we are singing out of tune or out of sync, for example? And if we embrace that 'imperfection' where might it lead? Answer: To the production of pleasure and joy, opportunities for action and awareness, and mutual participation - and music therapists who know their trade are acutely listening for and prepared to act on all or any format that musical action might assume.) We are learning that, in adopting adapted, unconventional or 'imperfect' forms, it is possible to produce the at least temporary dissolution, or transcendence, of difference (for example between 'abled' and 'disabled'). We are learning about new forms of beauty and sonority and with them, enhanced perception - and a richer potential for what John Cage once called, 'response ability' ('And sounds, when allowed to be themselves, do not require that those who hear them do so unfeelingly.' (Cage 1961:10)). We are learning that the notorious, 'latency issue' need not be an insurmountable problem. In fact, we are learning how it offers new resources - aesthetic and social - as caring for music 'at a distance' draws out new skills and new contributions from all involved (on this point, MacDonald et al 2021).

Many of the residents, allegedly without 'cognitive capacity' and in what is sometimes, simplistically, called a 'second childhood' (sic), nonetheless manage to work as musical 'pathfinders' (Knudsen et al 2018), engaging in social learning and helping to promote musical situations and helping each other to orient to the newfangled format of real-time/virtual music sessions. They do this by pointing to Gary Ansdell (the community music therapist, or as he has been called, the 'music man') when he appears on a television screen, or patting a neighbour's arm, or engaging in liminal musical activities such as tapping a foot or waving a hand and, of course, sounding out with voices - singing, whistling, humming, talking, shouting - registering presence in sound and space. They are Caring for Music. We are learning that all of us (residents, care staff, family, visitors, researchers - the 'differences' within and between these categories being often blurred) need human contact and that music, even, especially when close proximity is forbidden, can provide virtual human touch. We are learning that all of us seem to have a knack for establishing, maintaining and normalising new modes of contact and that this need is met through collaborative, 'artful' practices, thanks to the basic human capacity for musicality (Pavlicevic and Ansdell 2008). We are learning how the arts, in this case music, offer what Mariko 
Hara (2019) calls, 'permeable, sustainable' resources, spilling out, enriching and enabling other things to happen down the line.

Of course, imagination and creativity take many forms at different times within history and the life course and across spaces, physical and symbolic. We do not always recognise the creative acts of others as 'artful' (graffiti, parkour, noise, other people's music, styles, looks, tastes, and practices [see Miles 2016]) and when this happens, conflict occurs. Conflict over aesthetic matters happens precisely because of what is at stake - affordances for being, feeling, acting, being validated. We have seen, umpteen times how, viewed through certain lenses, putatively 'rich traditions' (the symphony, oil painting, Shakespeare, Beethoven) may be deemed uninteresting or hegemonic. And we have seen how, quote-unquote, decadent, dangerous, dissident, rebellious or amateur practices may be sanctified (and commodified). Again, it is the lens, the perceptual apparatus. And so, the school, in complex, multicultural times, has potential to become a place for Show \& Tell, for learning and peer-to-peer teaching about why it is that 'different' people do and love things 'differently', and for showcasing difference - as through artistic projects. When it does its job, the school, whether on line, in a physical classroom, or in the more liminal spaces where peers might congregate, offers a haven for learning - about ourselves, our potential differences and similarities, our potential as aesthetically configured beings in and over time. No wonder then that the study of arts in education is the study of a vital feature of wellbeing in complex and challenging times, and never more so than today.

\section{About the author}

Tia DeNora (Ph.D., FBA) is Professor of Music Sociology at the University of Exeter, Professor II in Music Therapy at the Grieg Academy, University of Bergen (GAMUT). Her current research examines music in scenes of late and end of life. She is also a member of the teams for the ESRC, MARCH Network for Mental Health project, the ARC Discovery Project, Social cohesion and resilience through intercultural music engagement, and Glasgow Improvisers Orchestra research project. Her latest book is Hope: the dream we carry, published by Palgrave Macmillan. 
Tia DeNora. Foreword: Reasons for Hope

\section{References}

Bergh, A. (2007). I'd like to Teach the World to Sing: Music and Conflict Resolution. Musicae Scientiae, 11(2), 141-157. https://doi.org/10.1177/10298649070110S207

Cage, J. (1961). Silence. Middletown, CT: Wesleyan University Press.

Care for Music - an ethnography of music in scenes of late and end of life. (20192022). Arts and Humanities Research Council. https://careformusic.org

Hara, M. and T. DeNora. (2019). The Goodness of Small Things: Why We Need Longitudinal and Ethnographic Studies of Music in Dementia Care. in Penelope Gouk, James Kennaway, Jacomien Prins, Wiebke Thormahlen (Eds.)The Routledge Companion to Music, Mind, and Well-being (pp 303315). London: Routledge.

Knudsen, J. S., G. S. Aglen, I Danbolt and N. Engesnes. (2018) Musical Pathfinders of the Kindergarten. Contemporary Issues in Early Childhood, 20(2). 163-176. https://doi.org/10.1177/1463949118756369

MacDonald, R.A.R., MacDonald, R., R. Burke, R. Birrell, T. DeNora and M. S. Donohue. (2021). Our Virtual Tribe: Sustaining and Enhancing Community via Online Music Improvisation. Frontiers in Psychology, 11(4076).https://doi.org/10.3389/fpsyg.2020.623640

Miles, A. and L. Gibson. (2016). Editorial. Everyday participation and cultural value. Special Issue, Cultural Trends, 25(3), 151-57. https://doi.org/10.1080/09548963.2016.1204043

Pavlicevic, M. and G. Ansdell (2008). Between communicative musicality and collaborative musicing: a perspective from community music therapy. In S. Malloch and C. Trevarthen (Eds). Communicative Musicality: Exploring the Basis of Human Companionship (pp. 357-76). Oxford: Oxford University Press. 